\title{
New records of Helotiales in Turkey
}

\author{
Oğuzhan Kaygusuz ${ }^{\mathrm{a}, *}$, Ömer Faruk Çolak ${ }^{\mathrm{b}}$ \\ a Department of Biology, Faculty of Science and Arts, Pamukkale University, Denizli 20020 Turkey \\ b Vocational School of Health Services, Süleyman Demirel University, Isparta 32260 Turkey
}

*Corresponding author, e-mail: okaygusuz03@gmail.com

Received 5 Apr 2017

Accepted 15 Aug 2017

ABSTRACT: Species of Ascocoryne sarcoides (Jacq.) J.W. Groves \& D.E. Wilson, Chlorociboria aeruginascens (Nyl.) Kanouse ex Ramamurthi, Korf \& Batra and Lachnellula agassizii (Berk. \& M.A. Curtis) Dennis, which are Helotiales, are described as new records for Turkey. Microscopic drawings and descriptions of the taxa are presented together with morphological photographs.

KEYWORDS: macrofungi, biodiversity, taxonomy, Ascomycota

\section{INTRODUCTION}

Helotiales Nannf. ex Korf \& Lizon, with 13 families, 501 genera, and approximately 3880 species, is the largest and most varied order in the Leotiomycetes (Ascomycota) ${ }^{1-3}$. Helotiales are a non-lichenized, inoperculate, and non-stromatic apothecial group of ascomycetes which show great morphological diversity because of their different nutritional strategies $^{2,4,5}$.

Morphological characteristics of the apothecia such as shape and colour, microscopic characteristics such as shape and size of asci and ascospores, apothecial ontogeny, and reaction of asci to Melzer's Reagent, ecological characteristics such as living on land or in water, and biological characteristics such as parasitic or saprophytic nutritional type have been used to identify and classify the families, genera, and species in the order Helotiales ${ }^{1,2}$. In addition, members of this order have distinguishing characteristics such as apothecia generally small and often brightly coloured, sessile or stipitate, cupulate or discoid ascomata, asci which are mostly small, thin-walled, without separable wall layers, and with an apical pore, and ascospores which are simple or transversely septate, not quite longitudinally symmetrical, mostly hyaline, and often smooth ${ }^{3,6}$.

Thanks to the geographical location and ecological, climatic, topographic, and geological factors, Turkey is as rich in fungal biodiversity as it is in plant species ${ }^{7,8}$. Numerous studies have been performed recently on the macrofungi of Turkey, and approximately 2600 taxa have been identified, but in comparison with this, little work has been carried out until now on the Helotiales which are represented by 65 taxa within 15 families and 38 genera in Turkey ${ }^{9-14}$.

The aim of this study was to explore the biodiversity of this country by reporting in Turkey for the first time the taxa of the order Helotiales Ascocoryne sarcoides (Jacq.) J.W. Groves \& D. E. Wilson, Chlorociboria aeruginascens (Nyl.) Kanouse ex Ramamurthi, Korf \& L. R. Batra and Lachnellula agassizii (Berk. \& M. A. Curtis) Dennis, and to contribute to future studies on the biogeographical distribution of these taxa.

\section{MATERIALS AND METHODS}

The specimens were collected from the provinces of Artvin and Denizli in Turkey in 2014 and 2015. Field studies were performed mostly in the autumn and spring, the period during which the macrofungi produce fruiting bodies. Morphological and ecological characteristics of the samples were noted and photographed in their natural habitats. After field work, specimens were brought to the laboratory where they were examined. Microscopic characters were observed by light microscope using $5 \% \mathrm{KOH}$, Melzer's Reagent, and distilled water.

Identification of the taxa and descriptive terms for morphological and microscopic features were based on the current literature ${ }^{15-26}$. After viewing the samples using the latest studies of Helotiales in a checklist of Turkish mycota ${ }^{9-14}$, they were considered as being new records for the macromycota of Turkey. Taxa, systematics, and author citations are quoted according to Kirk ${ }^{3}$, Index Fungorum (www.indexfungorum.org), and MycoBank (www.mycobank.org). The taxa investigated in this study are deposited in the fungarium of the Pamukkale University Mushroom Research and Application Centre (PAUMMER). 


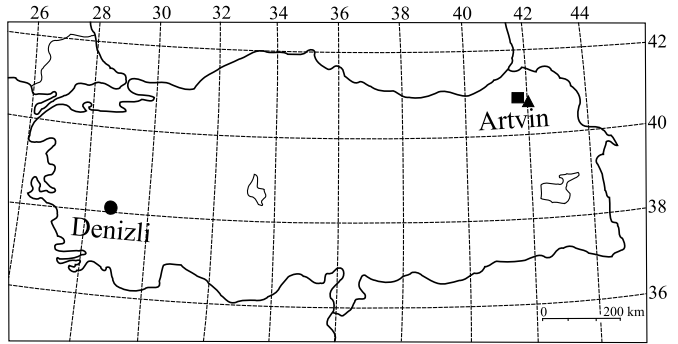

Fig. 1 Distribution of new records in different regions of Turkey according to the specimens examined. Square: Ascocoryne sarcoides; triangle: Chlorociboria aeruginascens; circle: Lachnellula agassizii.

\section{RESULTS}

The distribution of the specimens of fungi found in different regions of Turkey is given in Fig. 1. Ascocoryne sarcoides, Chlorociboria aeruginascens, and Lachnellula agassizii are presented together with descriptions, morphological photographs, and microscopic drawings.

Fungi Bartling

Ascomycota Whittaker

Pezizomycotina O.E. Erikss. \& Winka

Leotiomycetes O.E. Erikss. \& Winka

Helotiales Nannf. ex Korf \& Lizoň

Helotiaceae Rehm

Ascocoryne J.W. Groves \& D.E. Wilson

Ascocoryne sarcoides (Jacq.) J.W. Groves \& D.E. Wilson, Taxon 16(1): 40 (1967) (Fig. 2)

Basionym: Lichen sarcoides Jacq. -Miscellanea austriaca ad botanicum, chemiam et historiam naturalem spectantia 2:20 (1781).

Synonyms:

Bulgaria sarcoides (Jacq.) Fr. - Systema Mycologicum 2:168 (1822).

Coryne sarcoides (Jacq.) Tul. \& C. Tul. -(1865).

Helvella sarcoides (Jacq.) Dicks. -Fasciculus plantarum cryptogamicarum Britanniae 1:21 (1785).

Ombrophila sarcoides (Jacq.) W. Phillips. -A manual of the British Discomycetes, 323 (1887).

O. sarcoides (Jacq.) P. Karst. -86 (1871).

Pirobasidium sarcoides (Jacq.) Höhn. -Sber. Akad. Wiss. Wien, Math.-naturw. Kl., Abt. 1 111: 1002 [16 of repr.] (1902).

Tremella sarcoides (Jacq.) Fr. -Syst. mycol. (Lundae) 2: 217 (1822).

Macroscopic description: Apothecia 5-15 mm in diameter, spherical when young, later flattening, edges becoming wavy, becoming upturned cupshaped, stalk absent or short and poorly developed,
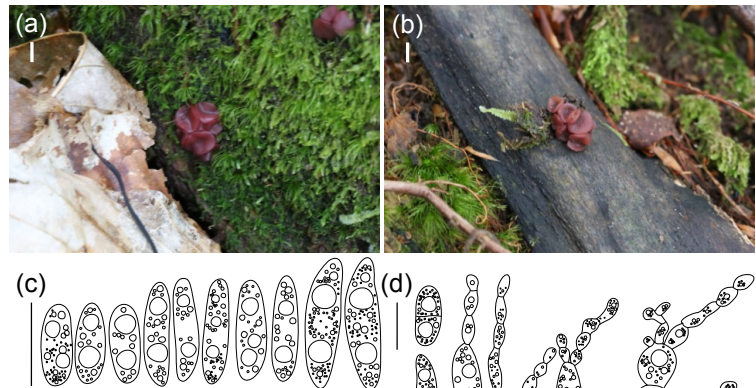

(e)

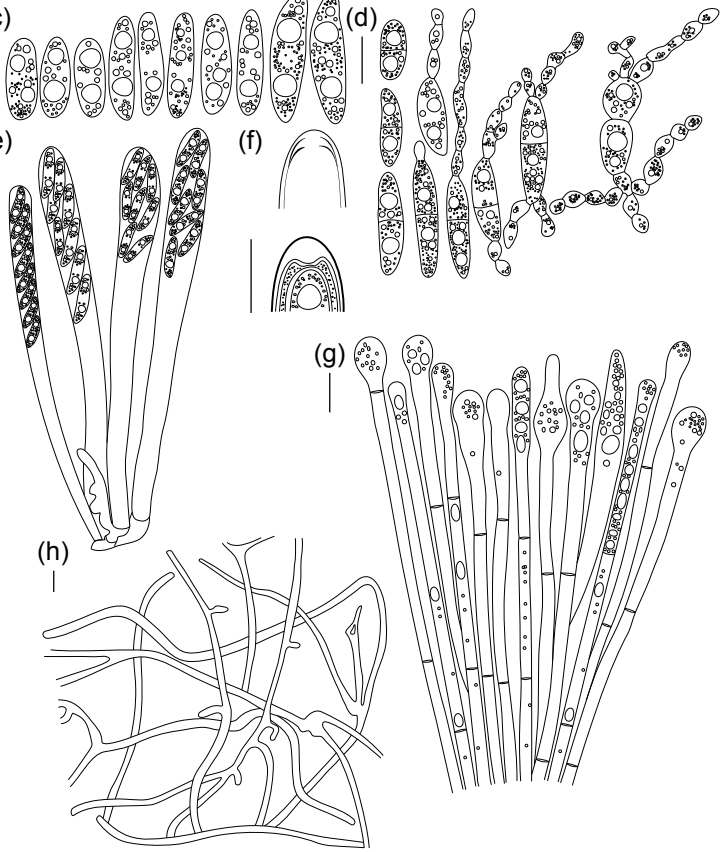

Fig. 2 Ascocoryne sarcoides; (a) and (b) fresh apothecia, on natural substrate; (c) ascospores; (d) germinated ascospores with septum and long germ tubes; (e) asci; (f) ascus apices (immature and mature); (g) paraphysis apices; (h) medullary excipulum. Scala bars: (a) and (b) $=10 \mathrm{~mm}$, (c) and (d) $=10 \mu \mathrm{m},(\mathrm{e})=15 \mu \mathrm{m}$, (f) $=$ $10 \mu \mathrm{m},(\mathrm{g})$ and $(\mathrm{h})=5 \mu \mathrm{m}$. All from OKA 298.

attached at the centre to the substrate, lobes at the edges frequently irregular. Fleshy part gelatinous. Hymenium smooth, slightly wrinkled when mature, reddish-pinkish or purplish.

Microscopic description: Ascospores 11-16 $\times 4$ $5.5 \mu \mathrm{m}$, ellipsoid with a smooth surface, hyaline, containing one or two drops of oil, with a single septum; white, creamy or yellowish tones. Asci 110$150 \times 8-10 \mu \mathrm{m}$ in size, threadlike-cylindrical, with 8 spores. Paraphyses numerous, filiform, cylindrical, 2-5 $\mu \mathrm{m}$ at apex, multiguttulate, unbranched, generally forked at the base, with few septa, sometimes thickening towards the apex. Medullary excipulum made up 2-4 $\mu \mathrm{m}$ wide, narrow interwoven hyphae. This fungus has an anamorphous conical or crater shape with irregular edges and a reddish or violet colour. 

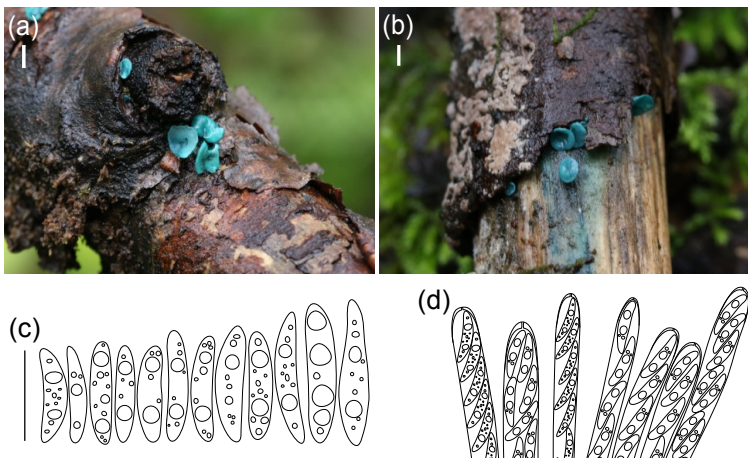

(d) (f)

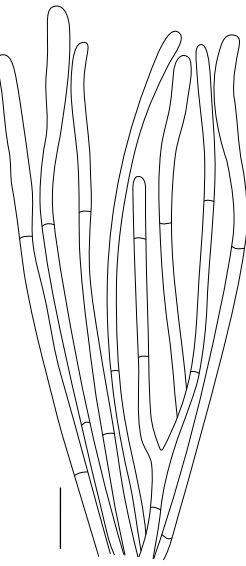

(e)

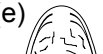

(e)

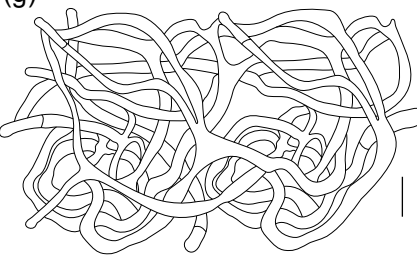

Fig. 3 Chlorociboria aeruginascens; (a) and (b) fresh apothecia developed on wood surface; (c) ascospores; (d) asci; (e) ascus apices (immature and mature); (f) paraphyses; (g) medullary excipulum with smooth-walled tomentum hyphae. Scala bars: (a) and (b) $=5 \mathrm{~mm}$, (c) $=5 \mu \mathrm{m}$, (d) and (f) $=10 \mu \mathrm{m},(\mathrm{g})=5 \mu \mathrm{m}$. All from OKA 307.

Ecology: This species is widely distributed in late summer and autumn, particularly in damp areas, on logs and branches particularly of broadleaved trees rotting on the ground. The species is saprophytic and as well as being found on organic waste, and it can be seen on various trees.

Specimens examined: TURKEY, Artvin, Borçka, Camili biosphere reserve area, on the damp, fallen and well-rotted trunks of Fagus orientalis Lipsky, 1465 m, 07.10.2015, OKA 298; on damp decayed wood of $F$. orientalis, part of which was underground, $1470 \mathrm{~m}, 14.10 .2015$, OKA 306.

Chlorociboriaceae Baral \& P.R. Johnst.

Chlorociboria Seaver ex Ramamurthi, Korf \& Batra

Chlorociboria aeruginascens (Nyl.) Kanouse ex Ramamurthi, Korf \& Batra, Mycologia 49(6): 858 (1958) [1957] (Fig. 3)

Basionym: Peziza aeruginascens Nyl. —(1869).
Synonyms:

Chlorosplenium aeruginascens (Nyl.) P. Karst. Bidrag till Kännedom av Finlands Natus ock Folk 19:103 (1871).

Chlorosplenium aeruginosum var. aeruginascens (Nyl.) P. Karst. —233 (1870).

Peziza aeruginascens (Nyl.) -(1869).

Macroscopic description: Apothecia $2-7 \mathrm{~mm}$ in width, disk or cup-shaped, on maturing becoming almost flat and taking the shape of a shallow cup. Hymenium smooth, between blue and green in colour; outer surface whitish when young, later a turquoise colour between blue and green, finally taking a flaky appearance. Stem $2-5 \mathrm{~mm}$ in length, cylindrical, generally attached away from the centre, occasionally centrally, and of a similar colour to the hymenium. Smell and taste indeterminate.

Microscopic description: Ascospores 5-8 $\times 1-$ $2.5 \mu \mathrm{m}$, fusiform to fusiform-elliptical, with an oil drop in the end part, surface smooth, hyaline and without septa. Asci 40-60 ×3.5-4.5 $\mu \mathrm{m}$ in size, narrow clavate or cylindrical clavate, with eight ascospores. Paraphyses 60-90 × 1.5-2.0 $\mu \mathrm{m}$, narrow clavate, threadlike, slightly widening at the ends, septate. Medullary excipulum textura intricate, numerous and intense, hyaline, narrow interwoven hyphae 2-4 $\mu \mathrm{m}$ wide, with walls thin, smoothwalled tomentum hyphae 1.5-2.5 $\mu \mathrm{m}$ diam, with short septate. Spore print varying from white to creamy.

Ecology: This species grows saprophytically solitary or in small groups on or in the wood of barked or rotted hardwood trees. It is easily seen on the forest floor because its mycelium appears green or light blue on the substrate on which it grows. The green mycelium can be seen all year round but the basidiomata generally appear in the autumn.

Specimens examined: TURKEY, Artvin, Borçka, Camili biosphere reserve area, on rotted and barked branches of Pinus sylvestris L. on the ground, $1380 \mathrm{~m}, 14.10 .2015$, OKA 307.

Hyaloscyphaceae Nannf.

Lachnellula P. Karst.

Lachnellula agassizii (Berk. \& M.A. Curtis) Dennis, Persoonia 2 (2): 183 (1962) (Fig. 4)

Basionym: Peziza agassizii Berk. \& M.A. Curtis, Grevillea -3 (28): 151 (1875).

Synonyms:

Atractobolus agassizii (Berk. \& M.A. Curtis) Kuntze -Revisio generum plantarum 3 (2): 445 (1898).

Dasyscypha agassizii (Berk. \& M.A. Curtis) Sacc. -(1889). 

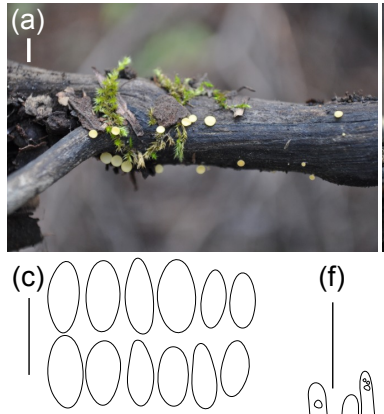

(d)

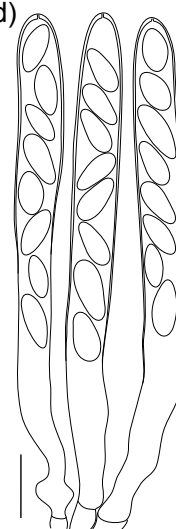

(f)

(e)

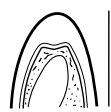

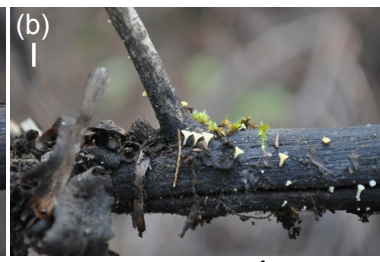

(g)

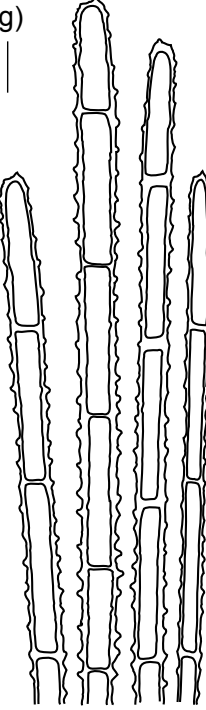

Fig. 4 Lachnellula agassizii; (a) and (b) fresh apothecia developed on wood surface; (c) ascospores; (d) asci; (e) apex of a mature ascus; (f) paraphyses; (g) excipular hairs. Scala bars: (a) and (b) $=10 \mathrm{~mm}$, (c) and (f) $=$ $10 \mu \mathrm{m},(\mathrm{g})=5 \mu \mathrm{m}$. All from OKA 100 .

Dasyscyphus agassizii (Berk. \& M.A. Curtis) Sacc. -Sylloge Fungorum 8:438 (1889).

Lachnella agassizii (Berk. \& M.A. Curtis) Seaver -The North American cup-fungi (Inoperculates) 3: 247 (1951).

Macroscopic description: Apothecia 3-7 $\mathrm{mm}$ in width, in the form of a shallow cup, with an incompletely developed white stalk; cap at first round then broadening, when wetted opens in a circular shape. Hymenium smooth, varying from bright yellow to yellowish orange; outer surface of the cap and its wavy edges densely covered with small flexible white hairs when young, on ageing the edges take on a fringed appearance, the outer surface is generally white or whitish. Has a short stalk and is attached to the substrate at its centre.

Microscopic description: Ascospores 6-9.5 × 2.5$4 \mu \mathrm{m}$, narrowly elliptical, surface smooth, uniseriate or biseriate, hyaline. Asci 50-75 $\times 3-5 \mu \mathrm{m}$, cylindrical to subcylindrical, eight spored. Paraphyses 55$80 \times 2-3.5 \mu \mathrm{m}$, distinctly filiform, almost spatulate at apex, sharply tapering below, occasionally slightly lanceolate, smooth, septate, sometimes branched at the base. Excipular hairs cylindrical, hyaline, relatively thick-walled, multiply septate by swollen or subacute, finely spiny, 2.5-4.0 $\mu \mathrm{m}$ diam.

Ecology: Generally found living saprophytically or parasitically in small groups on branches or pieces of wood of gymnosperms. A very small fungus, seen in spring or late autumn.

Specimens examined: TURKEY, Denizli, Buldan, Buldan upland lake area, or rotted and brokenup small branches or pieces of wood from Pinus nigra Arn. subsp. pallasiana (Lamb.) Holmboe, $982 \mathrm{~m}$, 02.10.2014, OKA 100.

\section{DISCUSSION}

Ascocoryne is a genus characterized by a gelatinous fruiting body and endophytic habits. When these fungi appear in a disorganized mass, they are similar to basidiomycete jelly fungi. Ascocoryne sarcoides is similar to A. cylichnium (Tul.) Korf in habitat and some macroscopic characteristics ${ }^{27-29}$. However, it has been shown by many taxonomists that these two species differ ${ }^{30}$. A. sarcoides has fruiting bodies which are bordered with light violet to greybrown, whereas $A$. cylichnium has fruiting bodies which are generally reddish purple to violet-pink. A. cylichnium has generally smaller apothecia (6$30 \mathrm{~mm})$, ascospores $(18-30 \times 4-6 \mu \mathrm{m})$, and asci $(200-220 \times 10-12 \mu \mathrm{m})^{16,19,23,25}$. Also, one of the most prominent characteristics of $A$. sarcoides is that asci and ascospores have one septum when they mature, the asci and ascospores of A. cylichnium have more than one septum ${ }^{16,19,23-25}$.

A. sarcoides is reported to have a wide distribution in forested areas of Europe (Finland, France, Britain, Iceland, Norway, Switzerland, and Germany), Australia, Asia (China), North America (Canada and Cuba), and South America (Chile) ${ }^{16,19,24,25,31}$.

A. sarcoides forms colonies on the dead wood, fallen trunks, logs buried in the ground or pieces lying on the ground of deciduous trees, particularly Carpinus, Fagus, and Quercus ${ }^{19,24}$. However, it has also been reported as growing apparently healthy on trees such as Abies, Picea, and Pinus ${ }^{19,31}$. Also, it is reported that $A$. sarcoides has been found to have a protective characteristic as an endophyte against rotting fungi, and that it is found as much in the roots of trees as in the branches ${ }^{32}$. In our study, the A. sarcoides examined was identified on a rotting log of Fagus orientalis.

The mycelium of Chlorociboria species produces xylindein, a unique blue-green pigment, on the 
substrate, making it one of the most recognizable fungi on the forest floor ${ }^{33}$. Chlorociboria aeruginascens has morphological characteristics which make it confusable with such species as $C$. aeruginosa (Oeder) Seaver ex Ramamurthi, Korf \& Batra, Chlorencoelia versiformis (Pers.) Dixon and Aeruginoscyphus sericeus (Alb. \& Schwein.) Dougoud. However, when these species are examined microscopically, they can be easily distinguished by the dimensions of their ascospores. C. aeruginascens has smaller ascospores varying between 5 and $8 \mu \mathrm{m}$, while the ascospores of other species are larger: C. aeruginosa 9-15 $\mu \mathrm{m}$, C. versiformis 9$15.5 \mu \mathrm{m}$ and A. sericeus 55-60 $\mu \mathrm{m}^{15,17,19-21,23,25}$. Also macroscopically, while $C$. aeruginascens has a number of fruiting bodies in one place, with asymmetric caps and generally stems which are away from the centre and only occasionally attached to the centre, $C$. aeruginosa has fruiting bodies which form separately, the caps are symmetrical and the stems are generally attached to the centre, and only occasionally away from the centre ${ }^{17}$.

C. aeruginascens is reported to have a wide distribution in forested areas in Europe, North America, and Asia ${ }^{15,20,21,34}$. This species grows particularly on many hardwood trees such as Acer sp., Betula sp., Fagus sp., Populus sp., Ulmus sp., and Quercus sp. ${ }^{17,33,35,36}$, but also on the well-rotted and damp logs and branches of the trees such as Pinus sp., Tsuga sp., and Cedrus sp. in groups or clusters, turning the substrate blue-green ${ }^{26,37}$. In this study, C. aeruginascens, which is a new record, was determined to be growing on pieces of the rotted branches of $P$. sylvestris.

The genus Lachnellula forms a natural group with a yellow disk and white excipular hairs, which generally grows saprophytically or parasitically on conifer wood. The species are macroscopically very similar to one another.

Because of the morphological similarity between Lachnellula agassizii and $L$. ciliate Dennis, L. gallica (P. Karst. \& Har.) Dennis, L. occidentalis (G.G. Hahn \& Ayers) Dharne, L. suecica (de Bary ex Fuckel) Nannf. and L. willkommii (R. Hartig) Dennis, it can be wrongly identified with confusion with these taxa. L. occidentalis is similar to L. agassizii in preferring Pinus and sometimes Picea as hosts. However, the upper surface of the cap of $L$. occidentalis is salmon-orange and has bigger ascospores of $11-20 \times 3.5-7.5 \mu \mathrm{m}$ in size, while the colour of the upper surface of the cap of $L$. agassizii is bright orange-yellow to yellow, and has smaller ascospores which are $6-9.5 \times 2.5-4 \mu \mathrm{m}$ in size.
L. willkommii is similar to L. agassizii in that it is a parasite of Pinus, and the upper surface of the cap varies from yellow to orange. However, microscopically, L. willkommii can be easily distinguished from $L$. agassizii by its larger ascospores $(15-26 \times 6-10 \mu \mathrm{m})$ and asci $(125-170 \times 9-14 \mu \mathrm{m})$. L. suecica is similar to $L$. agassizii in its preference for Pinus and Abies and the yellowish orange colour of the upper surface of the cap. However, L. suecica is different from L. agassizii in having 4.5-7 $\times 4$ $5.5 \mu \mathrm{m}$ globose type ascospores. Also, L. agassizii has 55-80 × 2-3.5 $\mu \mathrm{m}$ spatulate paraphyses, while L. gallica and L. ciliate have larger filiform paraphyses $(100-105 \times 1.5-2.5 \mu \mathrm{m}$ and 85-145 × 2-3 $\mu \mathrm{m}$, respectively), and so can be easily distinguished microscopically ${ }^{18,19,22,23,25}$.

L. agassizii is reported to have a distribution in Europe, Asia, and North America ${ }^{18,22,25}$. It is stated to grow saprophytically or weakly parasitically on the trunks or branches of gymnosperms such as Abies, Pinus, Picea, Tsuga, and Larix, forming small groups or clusters ${ }^{18,22,25}$. In our study, L. agassizii, which is a new record, was determined on a small, damp, rotted piece of a branch of $P$. nigra pallasiana.

According to the current literature, one taxon each of the Helotiales genera Ascocoryne and Chlorociboria, and five taxa from the genus Lachnellula, have been reported in Turkey. In this study, the species Ascocoryne sarcoides, Chlorociboria aeruginascens and Lachnellula agassizii are reported in Turkey for the first time, bringing the number of Helotiales in Turkey to $68^{9-14}$. Including the data which we have obtained, a contribution has been made to the biodiversity of the macromycota of Turkey, and findings have been reached which will be of use to future biogeographical distribution studies on these taxa, recorded in a different geographical region.

\section{REFERENCES}

1. Gernandt DS, Platt JL, Stone JK, Spatafora JW, HolstJensen A, Hamelin RC, Kohn LM (2001) Phylogenetics of Helotiales and Rhytismatales based on partial small subunit nuclear ribosomal DNA sequences. $M y$ cologia 93, 915-33.

2. Wang Z, Binder M, Schoch CL, Johnston PR, Spatafora JW, Hibbett DS (2006) Evolution of Helotialean fungi (Leotiomycetes, Pezizomycotina): a nuclear rDNA phylogeny. Mol Phylogenet Evol 41, 295-312.

3. Kirk PF, Cannon PF, Minter DW, Stalpers JA (2008) Dictionary of the Fungi, 10th edn, CAB International, Wallingford, UK.

4. Schoch CL, Sung GH, López-Giráldez F, Townsend JP, 
Miadlikowska J, Hofstetter V, Robbertse B, Matheny PB, et al (2009) The Ascomycota tree of life: a phylum-wide phylogeny clarifies the origin and evolution of fundamental reproductive and ecological traits. Syst Biol 58, 224-39.

5. Etayo J, Flakus A, Suija A, Kukwa M (2015) Macroskyttea parmotrematis gen. et sp. nov. (Helotiales, Leotiomycetes, Ascomycota), a new lichenicolous fungus from Bolivia. Phytotaxa 224, 247-57.

6. Chisti Y (1999) Modern systems of plant cleaning. In: Robinson R, Batt C, Patel P (eds) Encyclopedia of Food Microbiology, Academic Press, London, pp 1086-815.

7. Gezer K, Kaygusuz O, Çelik A, Işıloğlu M (2014) Ecological characteristics of truffles growing in Denizli Province, Turkey. J Food Agr Environ 12, 1105-9.

8. Gezer K, Kaygusuz O, Herken EH, Dodurga Y, Koizhaiganova M, Şeçme M (2016) Evaluation of the nutritional composition of wild edible mushroom Agaricus lanipes (F.H. Møller \& Jul. Schäff.) Hlaváček. Bangladesh J Bot 45, 161-6.

9. Sesli E, Denchev CM (2008) Checklists of the Myxomycetes, larger Ascomycetes, and larger Basidiomycetes in Turkey. Mycotaxon 106, 65-7.

10. Solak MH, Işıloğlu M, Kalmış E, Allı H (2015) Macrofungi of Turkey: Checklist, vol 2, Universities Offset, İzmir.

11. Uzun Y, Kaya A, Karacan İH, Kaya ÖF, Yakar S (2015) Neobulgaria Petr. and Trichopeziza Fuckel, two new genus record for Turkish Lachnaceae. J Fungus 6, 58-61.

12. Kaya A, Karacan İH, Uzun Y (2015) Three Phragmites Adans. inhabiting fungi taxa, new for Turkey. Biol Divers Conservat 8(1), 143-6.

13. Akata I, Kaya A, Uzun Y (2016) Two new genus records for Turkish Helotiales. Kastamonu Univ $J$ Forest Fac 16, 131-4.

14. Uzun Y, Kaya A, Karacan İH, Yakar S (2017) New additions to Turkish Hyaloscyphaceae. J Fungus 8, 13-9.

15. Ramamurthi CS, Korf RP, Batra LR (1957) A revision of the North American species of Chlorociboria (Sclerotiniaceae). Mycologia 49, 854-63.

16. Kallio T, Tamminen P (1974) Decay of spruce (Picea abies (L.) Karst.) in the Åland Islands. Acta Forest Fenn 138, 1-42.

17. Dixon JR (1975) Chlorosplenium and its segregates. II. The genera Chlorociboria and Chlorencoelia. Mycotaxon 1, 193-237.

18. Oguchi T (1981) Studies on the species of Lachnellula in Hokkaido: their morphology, physiology, and pathogenicity. Bull Hokkaido Forest Exp Stn 19, 187-247.

19. Breitenbach J, Kränzlin F (1984) Fungi of Switzerland, vol 1, Verlag Mykologia Lucerne, Switzerland.

20. Phillips R (1988) Mushrooms and Other Fungi of Great Britain and Europe, Pan Books, London.
21. Jordan M (1995) The Encyclopedia of Fungi of Britain and Europe, David \& Charles Book, Devon, UK.

22. Baral HO (2000) Dichotomous key to Lachnellula (worldwide). Unpublished, available at: www. ascofrance.com/uploads/forum_file/7637.doc.

23. Hansen L, Knudsen H (2000) Nordic Macromycetes (Ascomycetes), vol 1, Nordsvamp, Copenhagen.

24. Stancheva Y, Bencheva S, Pavlidis T, Ilieva M (2009) Atlas of Wood Decaying Fungi, Pensoft Publishers, Sofia-Moscow.

25. Beug M, Bessette AE, Bessette AR (2014) Ascomycete Fungi of North America: a Mushroom Reference Guide, vol 69, Univ of Texas Press, Austin.

26. Tudor D, Margaritescu S, Sánchez-Ramírez S, Robinson SC, Cooper PA, Moncalvo JM (2014) Morphological and molecular characterization of the two known North American Chlorociboria species and their anamorphs. Fungal Biol 118, 732-42.

27. Gücin F, Işıloğlu M (1995) Some new ascomycetes genera records for the fungi flora of Turkey. Turk $J$ Bot 19, 485-7.

28. Solak MH, Gücin F, Işıloğlu M, Kalmış E (1997) Wood-decaying fungi which were found in some provinces and their surroundings in the Northwest Anatolia. In: 11th World Forestry Congress, Antalya, pp 153-8.

29. Solak MH, Gücin F, Yılmaz F, Işıloğlu M (2003) Some macrofungi from Çanakkale Province. Herb J Syst Bot 10, 97-109.

30. Roll-Hansen F, Roll-Hansen H (1979) Ascocoryne species in living stems of Picea species. A literature review. Eur J Forest Pathol 9, 275-80.

31. EOL (2017) Encyclopedia of Life, www.eol.org.

32. Whitney RD, Fleming RL, Zhou K, Mossa DS (2002) Relationship of root rot to black spruce windfall and mortality following strip clear-cutting. Can $J$ Forest Res 32, 283-94.

33. Robinson SC, Laks PE (2010) Wood species affects laboratory colonization rates of Chlorociboria sp. Int Biodeter Biodegr 64, 305-8.

34. Robinson SC, Tudor D, Snider H, Cooper PA (2012) Stimulating growth and xylindein production of Chlorociboria aeruginascens in agar-based systems. AMB Express 2, 1-7.

35. Dennis RWG (1956) A revision of the British Helotiaceae in the herbarium of the Royal Botanic Gardens, Kew, with notes on related European species. Mycological Paper 62, Commonwealth Mycological Institute.

36. Blanchette RA, Wilmering AM, Baumeister M (1992) The use of green-stained wood caused by the fungus Chlorociboria in Intarsia masterpieces from the 15th century. Holzforschung 46, 225-32.

37. Jahn H (1990) Pilze an Bäumen, Patzer, Berlin. 